\title{
Assessment of Arsenic Levels in Water, Sediment, and Human Hair around Ie Seu'um Geothermal Manifestation Area, Aceh, Indonesia
}

\author{
Irnawati Irnawati ${ }^{1,2}$, Rinaldi Idroes ${ }^{3,4, *(\mathbb{D})}$, Utari Zulfiani ${ }^{3}$, Muslim Akmal ${ }^{5}$, Eko Suhartono ${ }^{6}$, \\ Ghazi Mauer Idroes ${ }^{7}$, Muslem Muslem ${ }^{8}$, Andi Lala ${ }^{3}$, Muhammad Yusuf ${ }^{3}$, Saiful Saiful ${ }^{3}$ (D) Khairi Suhud $^{3}$, \\ Eka Safitri $^{3}$ (D) and Zulkarnain Jalil ${ }^{9}$
}

check for updates

Citation: Irnawati, I.; Idroes, R.; Zulfiani, U.; Akmal, M.; Suhartono, E.; Idroes, G.M.; Muslem, M.; Lala, A.; Yusuf, M.; Saiful, S.; et al. Assessment of Arsenic Levels in Water, Sediment, and Human Hair around Ie Seu'um Geothermal Manifestation Area, Aceh, Indonesia. Water 2021, 13, 2343. https://doi.org/10.3390/w13172343

Academic Editor: David Widory

Received: 11 July 2021

Accepted: 23 August 2021

Published: 26 August 2021

Publisher's Note: MDPI stays neutral with regard to jurisdictional claims in published maps and institutional affiliations.

Copyright: (c) 2021 by the authors. Licensee MDPI, Basel, Switzerland. This article is an open access article distributed under the terms and conditions of the Creative Commons Attribution (CC BY) license (https:// creativecommons.org/licenses/by/ $4.0 /)$.
1 Graduate School of Mathematics and Applied Sciences, Universitas Syiah Kuala, Banda Aceh 23111, Indonesia; irnawati@poltekkesaceh.ac.id

2 Department of Midwifery, Health Polytechnic of Aceh Ministry of Health, Aceh Besar 23241, Indonesia

3 Department of Chemistry, Faculty of Mathematics and Natural Sciences, Universitas Syiah Kuala, Banda Aceh 23111, Indonesia; utarizulfiani@gmail.com (U.Z.); andy_beck42@yahoo.com (A.L.); iamyusufibrahim@gmail.com (M.Y.); saiful@unsyiah.ac.id (S.S.); khairi@unsyiah.ac.id (K.S.); e.safitri@unsyiah.ac.id (E.S.)

4 Department of Pharmacy, Faculty of Mathematics and Natural Sciences, Universitas Syiah Kuala, Banda Aceh 23111, Indonesia

5 Laboratory of Histology, Faculty of Veterinary Medicine, Universitas Syiah Kuala, Banda Aceh 23111, Indonesia; akmal_kh@unsyiah.ac.id

6 Department of Medical Chemistry/Biochemistry, Faculty of Medicine, Lambung Mangkurat University, Banjarbaru 70124, Indonesia; ekoantioxidant@gmail.com

7 Department of Chemical Engineering, Faculty of Engineering, Universitas Syiah Kuala, Banda Aceh 23111, Indonesia; idroesghazi@gmail.com

8 Department of Chemistry, Faculty of Science and Technology, Universitas Islam Negeri Ar-Raniry, Banda Aceh 23111, Indonesia; moslem_coolam@yahoo.com

9 Department of Physics, Faculty of Mathematics and Natural Sciences, Universitas Syiah Kuala, Banda Aceh 23111, Indonesia; zjalil@unsyiah.ac.id

* Correspondence: rinaldi.idroes@unsyiah.ac.id

Abstract: The concentration of arsenic in water, sediment, and resident hair in the Ie Seu'um geothermal manifestation area has been analyzed using the Atomic Graphite Furnace Atomic Absorption Spectrophotometry (GF-AAS) method. Sediment and hair samples were prepared by wet digestion using an acid solution. The measurement results were validated by linearity, Limit of Detection (LoD), Limit of Quantification (LoQ), Relative Standard Deviation (\%RSD), and \%Recovery. The validation test showed that this method is very linear, sensitive, accurate, and precise with a correlation coefficient of 0.9999 , LoD of $0.009 \mu \mathrm{g} / \mathrm{L}$, LoQ of $0.027 \mu \mathrm{g} / \mathrm{L}$, recovery values of $89.117-101.027 \%$ for hair samples and $88.337-105.175 \%$ for sediment samples, and RSD of $1.067 \%$. The sample test results showed that the hot springs contained the highest arsenic with levels of $166.73 \pm 0.0081 \mu \mathrm{g} / \mathrm{L}$ (IS1). In comparison, the water samples with the lowest arsenic levels were in the rivers that had not been in direct contact with the hot water (IS2) flow, which is $0.80 \pm 0.0036 \mu \mathrm{g} / \mathrm{L}$. All the river water samples that had been in contact with hot water were boreholes, and the resident boreholes located around hot water streams/rivers contaminated with arsenic were above the threshold. Only the river water that had not been in contact with hot water, refill water, and borehole waters outside the hot water flow were detected to be below the threshold level. All the sediment samples showed arsenic contamination, with levels ranging from $2.56-6.86 \mathrm{mg} / \mathrm{kg}$, and it was still within the normal limits recommended by the National Oceanic and Atmospheric Administration (NOAA). Arsenic exposures in communities living around the Ie Seu'um geothermal area, Mesjid Raya Sub-District, Aceh Besar District, Aceh Province, were very high, where 9 out of 10 respondents were positive for arsenic with levels ranging from $54.59-164.57 \mathrm{mg} / \mathrm{kg}$, which was already above the threshold set by the researchers.

Keywords: arsenic analysis; human hair; atomic absorption spectrophotometry; Ie Seu'um geothermal manifestation; Indonesia 


\section{Introduction}

Geothermal manifestations are phenomena on the Earth's surface in the form of geothermal energy potential characterized by symptoms such as fumaroles, steaming grounds, and hot springs with temperatures that are relatively higher than the surrounding one [1]. Ie Seu'um is one of the geothermal systems in the outflow zone of the Seulawah Agam Volcano, Aceh. The Ie Seu'um spring is estimated to have a temperature of $89-92{ }^{\circ} \mathrm{C}$ with a geothermal reservoir temperature in the range of $186-204^{\circ} \mathrm{C}$, an enthalpy medium system, and a type of chloride fluids. The mineral contents of water are quite various, including bicarbonate, sulfate, chloride, sodium, potassium, and magnesium [2]. The Ie Seu'um spring and its flow are in residential areas; therefore, the water is widely used by the residents and tourists.

The water that comes out of the Earth's crust generally contains numerous metal contents [3], including heavy metals, which are dangerous for organisms [4]. One of the heavy metals often found in geothermal water and sediment is arsenic $[5,6]$. There was a case of arsenic contamination reported in Bangladesh where polluted well water killed 3000 people and gave 125,000 victims skin cancer [7]. Another case of poisoning occurred in west Bengal. Millions of people in nine districts used ground water that was contaminated by arsenic for drinking water [7]. There has been no study reported on the incidence of the effects of arsenic exposure on the Ie Seu'um population. However, the local communities use the ground water and surface water, which has contact with geothermal water. This habit risks the communities by heavy metal exposure. The arsenic that enters the body can last a long time in the hair [8]. Arsenic will bind to the sulfhydryl (-SH) and cystine disulfide (-S-S) groups in the hair [9]. The amount of metal in the hair correlates with the amount of metal absorbed by the body [10].

The natural arsenic levels of $0.002 \mathrm{mg} / \mathrm{L}$ would increase 1000 times in the reservoir [11]. In Mexico, 6-51\% arsenic levels were detected in the geothermal reservoir. In El Salvador, the water from a reservoir close to a geothermal power plant contains an arsenic level of $8.9 \mathrm{mg} / \mathrm{L}$ [12]. Meanwhile, the geothermal energy in Japan contains arsenic ranging from 1.8-6.4 mg/L. In addition, the geothermal sources in Iceland and Hawaii are also indicated as sources of arsenic contamination. The presence of arsenic in geothermal water is influenced by the origin of magma and its chemical composition [11]. The geothermal water coming out from the tectonic plate of divergent boundaries generally has relatively low concentrations of arsenic, such as in the Icelandic hydrothermal system. In contrast, hydrothermal systems at or near the tectonic plate of convergent boundaries, such as in Japan, the Philippines, Indonesia, and New Zealand, tend to emit geothermal water with high concentrations of arsenic [13].

Using the Atomic Hydride Generation Atomic Absorption Spectrophotometry method, Yuksel et al. (2010) also reported arsenic levels in volunteer hair that ranged from 21$367 \mu \mathrm{g} / \mathrm{kg}$ [14]. Yuksel et al. (2015) also used Graphite Furnace Atomic Absorption Spectrophotometry (GF-AAS), another method for analyzing arsenic in samples, for arsenic analysis in miners and obtained 3.83-52.44 $\mu \mathrm{g} / \mathrm{L}$ of arsenic in their blood, 1.26-27.54 $\mu \mathrm{g} / \mathrm{L}$ in their urine, and $0.06-7.90 \mathrm{mg} / \mathrm{kg}$ in their hair [15].

Given the dangers of arsenic and the absence of research on the content of heavy metals in the Ie Seu'um geothermal manifestation area, collecting data on the content of heavy metals, such as arsenic, in geothermal water in the Ie Seu'um area is very important. In this study, the arsenic concentrations in the hot spring and its flow, the sediment, the water source around the hot spring and around its flow, and human hair in the Ie Seu'um area were measured, and the method used was validated. 


\section{Materials and Methods}

\subsection{Tools and Materials}

The tools used were as follows: Atomic Absorption Spectrophotometer (PinAAcle 900H PerkinElmer, Waltham, MA, USA), graphite furnace (THGA), autosampler (AS900), thermometer, $\mathrm{pH}$ meter, Total Dissolved Solid (TDS) meter, conductometer, salinity meter, shaker, analytical scales, hot plate with temperature control, 100-mesh sieve, 1000-milliliter polyethylene (PE) bottle, mortal, pestle, glass funnel, stirring rod, dropper pipette, micropipette, 100- and 50-milliliter volumetric flasks, an Erlenmeyer flask, measuring cup, beaker glass, stainless steel scissors, and a plastic scoop.

The materials used were argon gas, filter paper, $5 \times 7 \mathrm{~cm}$ plastic clip, $\mathrm{HNO}_{3}$ p.a., $\mathrm{HClO}_{4}$ p.a., $\mathrm{H}_{2} \mathrm{SO}_{4}$ p.a., and $\mathrm{As}_{2} \mathrm{SO}_{3}$ standard solution.

\subsection{Sampling Technique}

The samples include hot spring water, groundwater, surface water, sediment, and human hair from the Ie Seu'um geothermal manifestation area. Groundwaters were collected from hot springs and wells, whereas surface waters were collected from rivers and estuaries. There were 11 sample points where the samples were collected, starting from the hot springs to the estuary. The purpose of sampling along the river and estuary was to study arsenic distribution in the water flow. Well waters were collected from the tourist and residential areas. The wells in the residential areas, including boreholes and dug wells, were analyzed to study the exposure of arsenic in underground waters. Meanwhile, sediment samples were collected from the bottom of the center of the rivers and estuaries where water samples were also collected. The sampling points for water and sediment samples are shown in Table 1 and Figure 1, whereas the Ie Seu'um map, in general, is shown in Figure 2.

Table 1. Sampling point location for water and sediment samples in the Ie Seu'um area.

\begin{tabular}{ccc}
\hline Code & Locations & Coordinate \\
\hline IS1 & Hot Spring & $5^{\circ} 32^{\prime} 49^{\prime \prime} \mathrm{N} ; 95^{\circ} 32^{\prime} 55^{\prime \prime} \mathrm{E}$ \\
IS2 & River (Point 1) & $5^{\circ} 32^{\prime} 34^{\prime \prime} \mathrm{N} ; 95^{\circ} 32^{\prime} 46^{\prime \prime} \mathrm{E}$ \\
IS3 & River (Point 2) & $5^{\circ} 32^{\prime} 55^{\prime \prime} \mathrm{N} ; 95^{\circ} 32^{\prime} 31^{\prime \prime} \mathrm{E}$ \\
IS4 & River (Point 3) & $5^{\circ} 33^{\prime} 11^{\prime \prime} \mathrm{N} ; 95^{\circ} 32^{\prime} 08^{\prime \prime} \mathrm{E}$ \\
IS5 & Estuary & $5^{\circ} 35^{\prime} 31^{\prime \prime} \mathrm{N} ; 95^{\circ} 30^{\prime} 45^{\prime \prime} \mathrm{E}$ \\
IS6 & Borehole 1 & $5^{\circ} 33^{\prime} 11^{\prime \prime} \mathrm{N} ; 95^{\circ} 32^{\prime} 23^{\prime \prime} \mathrm{E}$ \\
IS7 & Treatment Drinking Water & $5^{\circ} 33^{\prime} 09^{\prime \prime} \mathrm{N} ; 95^{\circ} 32^{\prime} 21^{\prime \prime} \mathrm{E}$ \\
IS8 & Borehole 2 & $5^{\circ} 32^{\prime} 42^{\prime \prime} \mathrm{N} ; 95^{\circ} 32^{\prime} 35^{\prime \prime} \mathrm{E}$ \\
IS9 & Borehole 3 & $5^{\circ} 32^{\prime} 56^{\prime \prime} \mathrm{N} ; 95^{\circ} 32^{\prime} 31^{\prime \prime} \mathrm{E}$ \\
IS10 & Borehole 5 & $5^{\circ} 32^{\prime} 49^{\prime \prime} \mathrm{N} ; 95^{\circ} 32^{\prime} 49^{\prime \prime} \mathrm{E}$ \\
IS11 & Borehole 4 & $5^{\circ} 33^{\prime} 06^{\prime \prime} \mathrm{N} ; 95^{\circ} 32^{\prime} 23^{\prime \prime} \mathrm{E}$ \\
\hline
\end{tabular}

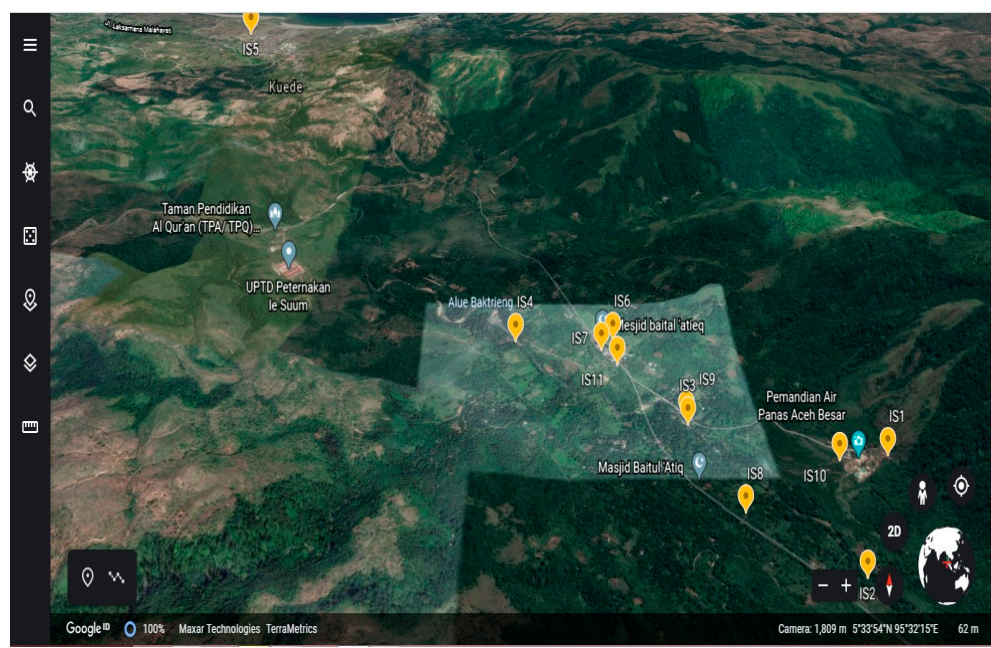

Figure 1. Sampling points based on Google Earth satellite image. 


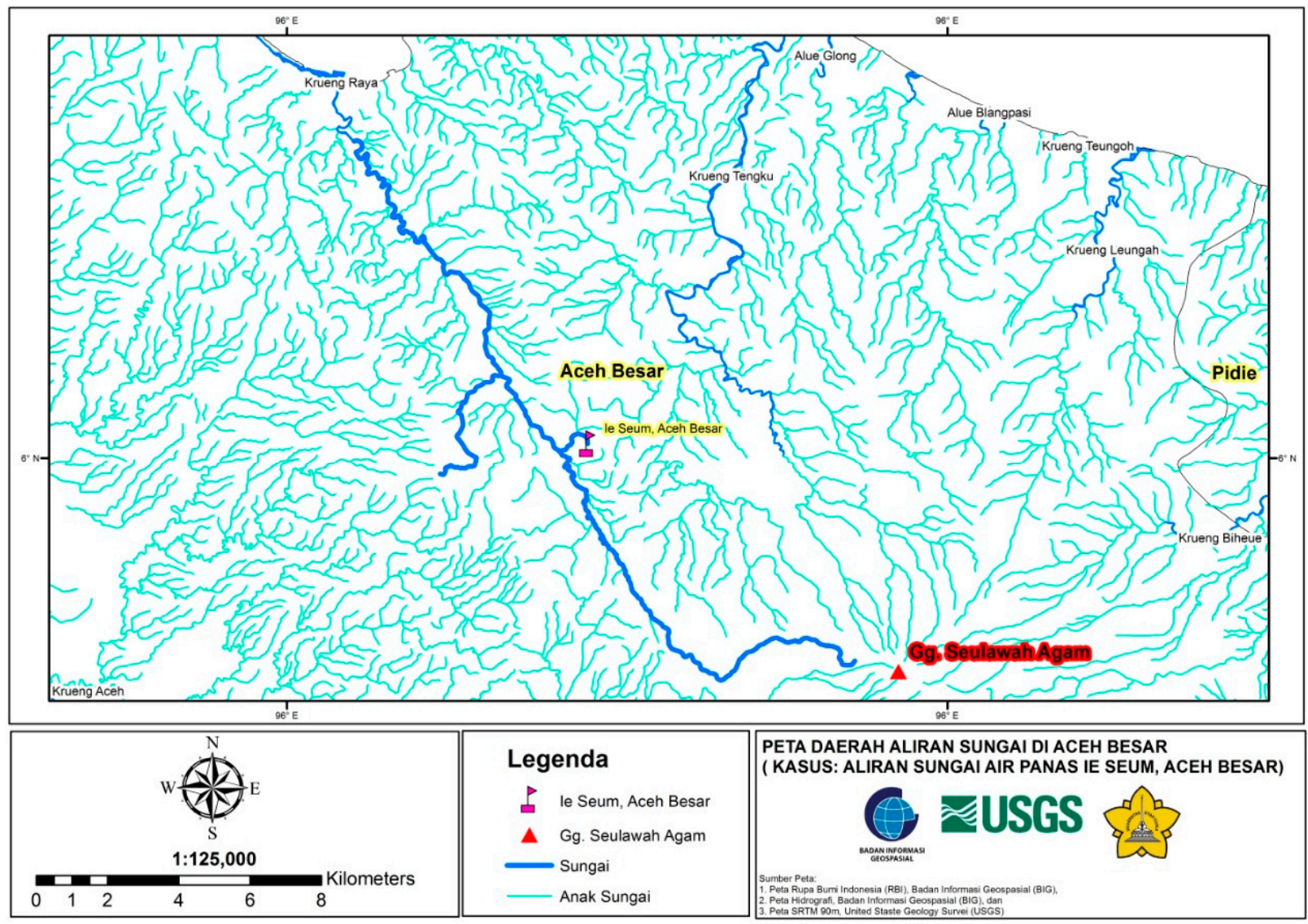

Figure 2. Map of the geothermal area of Ie Seu'um and its condition with Mt. Seulawah.

\subsubsection{Water Sampling}

Water samples were collected using a plastic scoop and stored in a PE bottle that had been rinsed once with nitric acid and three times with sample water. The samples were preserved with the addition of nitric acid until $\mathrm{pH}<2$ and cooled at $4 \pm 2{ }^{\circ} \mathrm{C}$ [16]. The samples were then sent to the laboratory for arsenic analysis. In situ analysis was also conducted to obtain data on temperature, $\mathrm{pH}$, TDS, conductivity, salinity, and the coordinates of the sampling points using portable digital thermometers, conductometers, $\mathrm{pH}$ meters, TDS meters, and GPS, respectively. For the control purpose, the distilled water was used as control water.

\subsubsection{Sediment Samplings}

Sediment samples from the bottom of river were collected using a stainless-steel spoon from several points of the river with the body of the researcher facing the upstream of the river. The samples were then mixed and stored on plastic clips labeled with a predetermined code [17].

\subsubsection{Hair Sampling}

Hair samples were collected from as many as five points on the head of each respondent. The samples were obtained from residents living around the Ie Seu'um area. Respondents consisted of 10 women according to the criteria.

As for the inclusion criteria of the research, subjects are female; aged 18-49 years; living in Ie Seu'um Village; willing to be a research respondent; do not use chemicals on their hair, such as dyes and hair straighteners; do not suffer from chronic diseases; and use water sourced from Ie Seu'um ground water for daily needs. 
Hair samples in the control group were taken from respondents with inclusion criteria that were matched with the control group, namely, female gender, aged 18-49 years, do not use chemicals on hair such as hair coloring and straightening, do not suffer from chronic diseases, have never lived around Ie Seum or other geothermal areas.

Before taking hair samples from the subjects who became research respondents, the respondents first signed a letter of willingness to become research respondents that had been prepared by the research team. The letter of willingness to be a research respondent has been known and approved by the head of public health center Mesjid Raya District, Aceh Besar Regency, and the local Village Head.

The hair was cut $0.5 \mathrm{~cm}$ from the roots using stainless steel scissors. Hair samples must be dry and should not be wet or oily [10].

\subsection{Sample Preparation}

\subsubsection{Sediment Sample Preparation}

The sediment sample was cleaned of impurities such as plastic scraps and leaves. Then, the sample was dried at room temperature, crushed until homogeneous, and sieved with a 100-mesh sieve. The sample powder (3 g) was placed into a 250-milliliter Erlenmeyer flask. Demineralized water $(25 \mathrm{~mL})$ was added and stirred. $\mathrm{HNO}_{3}$ p.a. $(10 \mathrm{~mL})$ and 3 boiling stones were added to the mixture. The Erlenmeyer flask was closed with a watch glass and heated until the remaining volume of the mixture reached $\pm 10 \mathrm{~mL}$. After cooling, $\mathrm{HClO}_{4}$ $(5 \mathrm{~mL})$ was added to the mixture and heated again until it formed a white smoke, and the solution color turned clear yellowish. Afterward, heating was continued for $30 \mathrm{~min}$. After cooling, the solution was filtered and diluted with deionized water in a 100-milliliter volumetric flask [18].

\subsubsection{Hair Sample Preparation}

The hair sample was weighed at $0.2 \mathrm{~g}$ and washed with deionized water. The sample was then shaken for about 30 min using a mechanical shaker. The sample was placed into a 100-milliliter Erlenmeyer flask, and $\mathrm{H}_{2} \mathrm{SO}_{4}$ p.a. $(4 \mathrm{~mL})$ and $\mathrm{HNO}_{3}$ p.a. $(3 \mathrm{~mL})$ were added. The Erlenmeyer flask was heated with the gradual addition of $\mathrm{HNO}_{3}$ until the sample color turned brownish or blackish. $\mathrm{HClO}_{4}(2 \mathrm{~mL})$ was added and heated again until the solution color turned clear yellowish. The liquid extract was then diluted with deionized water in a 100-milliliter volumetric flask [19].

\subsection{Arsenic Analysis with GF-AAS}

The solution $(20 \mu \mathrm{L})$ was injected through the autosampler into the furnace tube for atomization. Arsenic levels were measured at $(\lambda) 193.70 \mathrm{~nm}$. Each sample was measured in three repetitions [20].

\subsection{Method Validation}

The validation parameters observed were linearity, precision, \%Recovery, LoD, and LoQ. Linearity is determined by standard measurements at seven concentration levels. Precision is determined via standard measurements at six repetitions. \%Recovery is determined by measuring the spiked sample. LoD and LoQ are determined based on the acquisition of the calibration curve regression line [21]. The equations are presented in Table 2. 
Table 2. Formula for uncertainty measurement.

\begin{tabular}{|c|c|}
\hline Name & Formula \\
\hline Standard Deviation of Regression & $S r=\sqrt{\frac{S_{y y}-m^{2} S_{x x}}{N-2}}$ \\
\hline Standard Deviation of Slope & $S_{m}=\sqrt{\frac{S_{y}^{2}}{\sum\left(\overline{X-X_{i}}\right)^{2}}}=\sqrt{\frac{S_{y}^{2}}{\sum x_{i}^{2}-\left(\sum X_{i}\right)^{2} / N}}$ \\
\hline Standard Deviation of Intercept & $S_{b}=S_{y} \sqrt{\frac{S_{y}^{2} \sum X_{i}^{2}}{N \sum X_{i}^{2}-\left(X_{i}\right)^{2}}}=S_{y} \sqrt{\frac{1}{N-\left(\sum X_{I}\right)^{2} / \sum X_{i}^{2}}}$ \\
\hline Standard Deviation of the Concentration & $S c=\frac{S_{i}}{m} \sqrt{\frac{1}{M}+\frac{1}{N}+\frac{\left(Y_{c}-Y_{a v e}\right)^{2}}{m^{2} S_{x x}}}$ \\
\hline $\begin{array}{l}\text { Limit of Detection } \\
\text { Limit of Quantification }\end{array}$ & $\begin{aligned} \mathrm{LoD} & =3.3 \times \frac{\mathrm{Sr}}{\text { slope }} \\
\mathrm{LoQ} & =10 \times \frac{\mathrm{Sr}}{\text { slope }}\end{aligned}$ \\
\hline
\end{tabular}

\subsection{Calculation of the Standard Deviation of Concentration (Sc)}

The uncertainty of the concentration measurement results of each parameter was presented in standard deviation values and some statistical function data using the LINEST function in Microsoft Excel (Microsoft Corporation, Redmond, WA, USA). The calculation results obtained statistical function data, including slope $(\mathrm{m})$ and its standard deviation $(\mathrm{Sm})$, intercept (b) and its standard deviation $(\mathrm{Sb})$, the determination of coefficient $(\mathrm{R})$, regression standard deviation (Sr), and standard deviation of concentration (Sc). The equations used in calculating standard deviation and statistical functions are presented in Table 2 [22].

\section{Result and Discussion}

\subsection{Water Sample Characteristics}

The parameters for the in situ analysis of water samples were $\mathrm{pH}$, TDS, EC, temperature, and salinity. The result of the in situ analysis is shown in Table 3.

Table 3. In situ data of water, river, and well samples in the field.

\begin{tabular}{cccccc}
\hline Code & $\mathbf{p H} \pm \mathbf{S D}$ & $\mathbf{T D S} \pm \mathbf{S D}(\mathbf{m g} / \mathbf{L})$ & $\mathbf{E C} \pm \mathbf{S D}(\boldsymbol{\mu S} / \mathbf{c m})$ & $\mathbf{T} \pm \mathbf{S D}\left({ }^{\circ} \mathbf{C}\right)$ & Salinity $\pm \mathbf{S D}(\% \mathbf{)})$ \\
\hline IS1 & $6.65 \pm 0.019$ & $4534 \pm 0.008$ & $9686 \pm 0.802$ & $85.46 \pm 0.330$ & $17.8 \pm 0.054$ \\
IS2 & $7.57 \pm 0.008$ & $56.74 \pm 0.559$ & $117.6 \pm 1.550$ & $27.16 \pm 0.015$ & $0.12 \pm 0.044$ \\
IS3 & $7.58 \pm 0.007$ & $1614 \pm 0.118$ & $3892 \pm 0.463$ & $27.88 \pm 0.028$ & $0.94 \pm 0.114$ \\
IS4 & $7.64 \pm 0.008$ & $3232 \pm 0.327$ & $5086 \pm 1.058$ & $28.61 \pm 0.017$ & $0.58 \pm 0.083$ \\
IS5 & $7.52 \pm 0.010$ & $5564 \pm 0.247$ & $9536 \pm 0.319$ & $30.85 \pm 0.030$ & $19.08 \pm 0.752$ \\
IS6 & $7.49 \pm 0.008$ & $10.9 \pm 1.466$ & $26.66 \pm 0.932$ & $28.44 \pm 0.011$ & $0.14 \pm 0.054$ \\
IS7 & $6.15 \pm 0.008$ & $10.344 \pm 0.307$ & $24.94 \pm 0.378$ & $29.22 \pm 0.016$ & $0.12 \pm 0.044$ \\
IS8 & $6.66 \pm 0.007$ & $9.022 \pm 0.813$ & $13.52 \pm 1.516$ & $29.05 \pm 0.020$ & $0.12 \pm 0.044$ \\
IS9 & $6.63 \pm 0.008$ & $3.48 \pm 0.080$ & $5.946 \pm 0.858$ & $29.36 \pm 0.012$ & $0.16 \pm 0.89$ \\
IS10 & $6.55 \pm 0.008$ & $2270 \pm 0.05$ & $4526 \pm 0.486$ & $36.13 \pm 0.008$ & $8.46 \pm 0.320$ \\
IS11 & $6.94 \pm 0.011$ & $117.94 \pm 1.621$ & $520 \pm 1.224$ & $29.88 \pm 0.008$ & $1.06 \pm 0.054$ \\
\hline
\end{tabular}

The results of the in situ analysis (Table 3) showed that the acidity level $(\mathrm{pH})$ of all the water samples were relatively neutral $(\mathrm{pH}=6.15-7.64)$, which still qualify for drinking and clean water (6.5 $\geq \mathrm{pH} \leq 8.5)$, except treatment drinking water (IS7) [23]. The TDS test showed that the water in the geothermal manifestation location, namely, the hot springs (IS1) and borehole five (IS10), and the rivers that have been in direct contact with hot water flows (IS3, IS4, and IS5) had very high TDS levels (1614-4534 mg/L), thus not qualifying to be used either as drinking water or clean water. The water outside of the manifestation location, namely, borehole one (IS6), the treatment drinking water (IS7), and the community boreholes (IS8, IS9, and IS11), and the rivers that have not been in direct contact with the hot water flow (IS2) had low TDS levels (3.48-117.94 mg/L), thus, qualifying to be used as 
both drinking water and clean water (TDS $\leq 500$ for drinking water and TDS $\leq 1000$ for clean water) [23].

The EC value was measured based on electrical conductivity from the electrolyte contained in the water sample. Similar to the TDS levels, the EC value of the water at the geothermal manifestation location (IS1 and IS10) and the rivers that have been in direct contact with the hot water flows (IS3, IS4, and IS5) had very high EC values $(>1000 \mu \mathrm{S} / \mathrm{cm})$; thus, indicating the presence of ions from hot springs in the surrounding water.

The salinity levels of the hot springs (IS1) and the boreholes (IS10) were also quite high, which were 17.8 and $8.46 \%$, respectively, indicating a fairly high salt content in the geothermal water. This condition also affected the salinity of the river water, which has been in contact with hot water (IS3 and IS4), where the salinity increased up to four times compared with the natural river water (IS2). The water in the estuary (IS5) had the highest salinity, which was $19.08 \%$, where the influence of seawater was already present. Meanwhile, the salinity of the well, refill, and borehole waters were quite normal and in accordance with the quality standard of freshwater salinity, which is $<0.5 \%$ [24].

There was an increase in the TDS and EC values of the IS11 resident well compared with the other resident wells. This was influenced by the location of the IS11 well, which was quite close to the geothermal manifestation location. The IS11 well is also directly around the hot water flow. The water temperature of the hot springs was quite high, which is up to $85^{\circ} \mathrm{C}$. However, the other water temperatures were normal and in accordance with the temperature of the surrounding environment, which is $27-30^{\circ} \mathrm{C}$, except for the boreholes (IS10) in the geothermal manifestation location, which was warm $\left(36^{\circ} \mathrm{C}\right)$. Based on the results of the in situ analysis, only the resident boreholes (IS8, IS9, and IS11), the boreholes (IS6), the treatment drinking water, and the rivers that have not been in contact with hot water flow are still suitable for daily use for the community in the area. Meanwhile, the water in the manifestation location and the river waters that have been in contact with the hot water flow do not qualify for clean water.

\subsection{Method Validation}

\subsubsection{Calibration Curves and LoD/LoQ}

The calibration curve obtained from this study is shown in Figure 3. The $\mathrm{R}^{2}$ value obtained from the curve was 0.9999, which was calculated based on Microsoft Excel. This showed that the calibration curve obtained a good correlation between the standard concentration and instrument response. Therefore, the calibration curve has the feasibility of analyzing samples. Based on the calibration curve, the LoD and LoQ values were 0.009 and $0.027 \mu \mathrm{g} / \mathrm{L}$, which were statistically calculated using the LINEST function (Table 4) in Microsoft Excel [22].

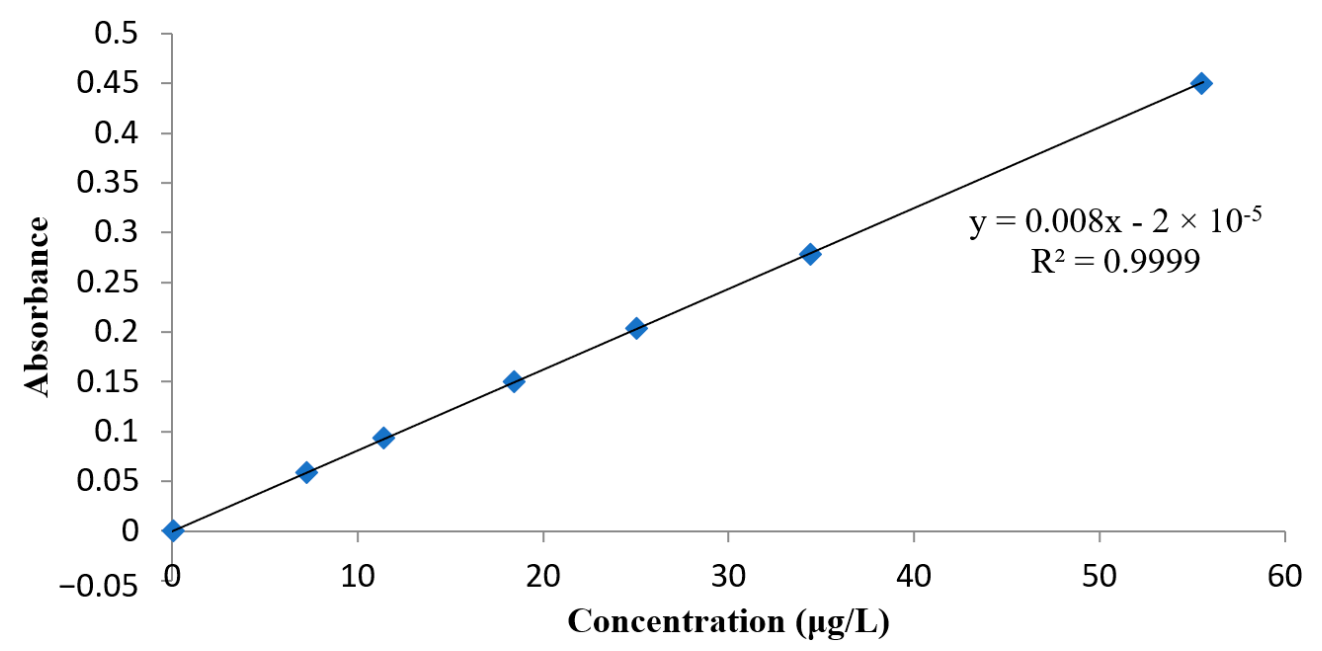

Figure 3. Calibration curve for arsenic standards. 
Table 4. The linearity and the uncertainty of the calibration curve threshold (Figure 3).

\begin{tabular}{cc}
\hline Name & Result \\
\hline Slope & 0.00811667 \\
Intercept & $-2.09278 \times 10^{-5}$ \\
Standard Deviation of Slope (Sm) & 0.00000048 \\
Standard Deviation of Intercept (Sb) & $1.3402 \times 10^{-5}$ \\
Coefficient of Determination ( $\left.{ }^{2}\right)$ & 0.99999998 \\
Standard Deviation of Regression (Sr) & $2.21382 \times 10^{-5}$ \\
Sum of Square Regression & 0.13942563 \\
Sum of Square Residual & $2.45049 \times 10^{-5}$ \\
\hline
\end{tabular}

\subsubsection{Precision and \%Recovery}

Based on Table 5, the \%Recovery of the hair and sediment samples, which have been spiked with $30 \mu \mathrm{g} / \mathrm{L}$ arsenic standard solution, was in the allowable range of 70-125\% [25]. This suggested that the method used for hair and sediment preparation is suitable for arsenic analysis. The precision was also tested using $30 \mu \mathrm{g} / \mathrm{L}$ arsenic standard solutions, and the measurement showed good precision with \%RSD $<2 \%$ [25].

Table 5. Precision values of arsenic metal and \%Recovery for hair and sediment samples.

\begin{tabular}{ccccc}
\hline \multicolumn{2}{c}{ \%Recovery (Hair) } & \multicolumn{2}{c}{ \%Recovery (Sediment) } & \multirow{2}{*}{ \%RSD } \\
\cline { 1 - 3 } Sample & Recovery (\%) & Sample & Recovery (\%) & \\
\hline RS1 & 89.117 & SS1 & 105.175 & \\
RS2 & 98.850 & SS2 & 89.815 & \multirow{2}{*}{1.067} \\
RS3 & 101.027 & SS3 & 88.337 & \\
\hline
\end{tabular}

\subsection{Arsenic Analysis in Water Samples}

The validated method was applied to measure the arsenic levels in the water samples, the sediment, and resident hair in the geothermal manifestation area of Ie Seu'um, Seulawah Agam Volcano, Aceh. The water samples analyzed included the hot springs (IS1), the rivers (IS2, IS3, and IS4), the estuary (IS5), the boreholes (IS6), the treatment drinking water (IS7), the resident boreholes (IS8, IS9, and IS11), and the boreholes in a geothermal manifestation location (IS10). The results showed that arsenic was detected in all the water samples at various concentrations (Table 6).

Table 6. Arsenic levels in water samples.

\begin{tabular}{ccc}
\hline No. & Code & Concentration $(\mu \mathbf{g} / \mathbf{L}) \pm \mathbf{S c}$ \\
\hline 1. & IS1 & $166.73 \pm 0.008$ \\
2. & IS2 & $0.80 \pm 0.003$ \\
3. & IS3 & $136.80 \pm 0.007$ \\
4. & IS4 & $100.04 \pm 0.006$ \\
5. & IS5 & $60.66 \pm 0.004$ \\
6. & IS6 & $106.82 \pm 0.006$ \\
7. & IS7 & $9.53 \pm 0.004$ \\
8. & IS8 & $12.45 \pm 0.004$ \\
9. & IS9 & $127.31 \pm 0.007$ \\
10. & IS10 & $146.71 \pm 0.007$ \\
11. & IS11 & $87.60 \pm 0.005$ \\
\hline
\end{tabular}

The hot springs (IS1) showed very high arsenic levels of $166.73 \mu \mathrm{g} / \mathrm{L}$, which are dangerous if exposed to organisms. This also affected the high levels of arsenic exposure to the borehole water in the manifestation location (IS10) and the river waters that have been in direct contact with hot water (IS3, IS4, and IS5). Both of these waters cannot be used by the surrounding community either as drinking water or clean water because they did not 
pass the water quality standards $(10 \mu \mathrm{g} / \mathrm{L}$ for drinking water and $50 \mu \mathrm{g} / \mathrm{L}$ for clean water $)$ recommended by Menkes RI (2017) and the WHO (2011) [26,27]. There was a decrease in the arsenic levels in the river flow from the contact point with hot water to the estuary, but the arsenic levels still exceeded the quality standard. This decrease was expected because of the dissolution by seawater. High arsenic levels were also detected in the borehole water (IS6) and the two resident boreholes (IS9 and IS11). These well waters were assumed to be exposed to arsenic from underground water, which has been exposed to arsenic from hot water. Meanwhile, the resident borehole water of IS9 and IS11 located along the river, which has been in contact with hot water, were exposed to arsenic from the river water.

Low levels of arsenic were detected in the river water (IS2), the treatment drinking water (IS7), and the boreholes (IS8). The arsenic levels in these three waters are at a safe level to be used by the community as clean water. Even the arsenic levels in the river water (IS2) and the treatment drinking water (IS7) still qualify for drinking water quality standards. The low levels of arsenic in the river water (IS2) are due to its location, which has not been in contact with hot water. The same thing was also shown in the resident borehole water (IS8), which was around the river water (IS2) with low arsenic levels. The low levels of arsenic in the treatment drinking water (IS7) are due to the fact that the water has been treated for consumption purposes.

\subsection{Arsenic Analysis in Sediment Samples}

Arsenic levels in the sediment were also identified along with the river flow at the same point as the water sampling. The results showed that the arsenic levels in the river flow sediments that had been in contact with hot water (IS3, IS4, and IS5) were twice higher than the sediments of drained water, which had not been in contact with hot water (Table 7). This showed that hot water contributed to arsenic distribution in river sediments. However, the arsenic levels in the sediment were still normal. Based on Salim et al. (2009), the normal levels of arsenic in river sediments are in the range of $10-33 \mathrm{mg} / \mathrm{kg}$, which corresponds to the value recommended by the National Oceanic and Atmospheric Administration (NOAA) [28].

Table 7. Arsenic level in sediment samples.

\begin{tabular}{ccc}
\hline No & Code & Content $\pm \mathbf{S c}(\mathbf{m g} / \mathbf{k g})$ \\
\hline 1. & IS2 & $2.562 \pm 0.003$ \\
2. & IS3 & $6.865 \pm 0.005$ \\
3. & IS4 & $5.281 \pm 0.004$ \\
4. & IS5 & $5.953 \pm 0.004$ \\
\hline
\end{tabular}

The lower arsenic levels in the sediment than those in the water can be caused by several factors, one of which is the difference in $\mathrm{pH}$ between the sediment and the water. Arsenic tends to be distributed to the water phase when the $\mathrm{pH}$ of the sediment is lower than that of the water. The reduction environment tends to liberate arsenic, whereas the oxidation environment in the presence of iron ions can absorb arsenic very well [24]. Besides these factors, physical factors, such as water flow and erosion, are also causes of the reduced arsenic levels in the sediment.

\subsection{Arsenic Analysis in Hair Samples}

The hair samples obtained from 10 residents living around the Ie Seu'um area were analyzed using GF-AAS, and the results were shown in Table 8. 
Table 8. Arsenic levels in hair samples.

\begin{tabular}{cccc}
\hline No. & Code & Age & Content \pm Sc (mg/kg) \\
\hline 1. & A1 & 27 & $54.59 \pm 0.003$ \\
2. & A2 & 43 & $128.07 \pm 0.005$ \\
3. & A3 & 23 & $115.44 \pm 0.005$ \\
4. & A4 & 43 & $127.15 \pm 0.005$ \\
5. & A5 & 22 & $98.69 \pm 0.004$ \\
6. & A6 & 27 & n.d. \\
7. & A7 & 20 & $66.47 \pm 0.004$ \\
8. & A8 & 49 & $164.57 \pm 0.006$ \\
9. & A9 & 22 & $110.13 \pm 0.005$ \\
10. & A10 & 27 & $116.32 \pm 0.005$ \\
\hline
\end{tabular}

n.d.: no detection.

Arsenic exposures in people living around the geothermal areas were identified by measuring the accumulation of arsenic in hair. Ten people of various ages were used as respondents. The results showed that 9 out of the 10 respondents had been exposed to various arsenic levels (Table 8). It should be noted that the nine people contaminated with arsenic live close to the rivers contaminated with arsenic originating from the Ie Seu'um spring, while the one person who is not contaminated lives close to the streams of water that are not contaminated with arsenic but are still in the Ie Seu'um area. This showed the high arsenic contamination in communities around the geothermal area. Although there is no quality standard issued by the government regarding arsenic in humans, several researchers have determined the level of arsenic poisoning in the human body. Wu and Chen (2010) stated that arsenic levels above $1 \mathrm{mg} / \mathrm{kg}$ are categorized as poisoning [29]. This limit is determined based on the average arsenic level in the hair of healthy people in China, which was $1 \mathrm{mg} / \mathrm{kg}$. However, according to Ali (2003), arsenic levels above $3 \mathrm{mg} / \mathrm{kg}$ are categorized as poisoning [30]. Arsenic levels around $100 \mathrm{mg} / \mathrm{kg}$ were often found in people who were directly contaminated with arsenic material. The Mayo Clinic (2020) reported that the arsenic level in hair that has caused death is $210 \mathrm{mg} / \mathrm{kg}$ [31].

Referring to the standards set by Wu and Chen (2010) and Ali (2003), the arsenic levels in the hair samples have passed the normal threshold for arsenic poisoning $[29,30]$. The high arsenic levels in human hair were due to arsenic accumulation through contaminated water, especially long time and continuous consumption. Although water treatment exists in the area with arsenic levels within safe limits, not all the residents used this water for consumption purposes.

Based on short interviews with the respondents, some residents used river water as drinking water. This is caused by the unawareness of the residents of the presence of heavy metals in the water due to geothermal activity. Moreover, arsenic poisoning in small doses does not show any symptoms in the short term; therefore, the symptoms of arsenic poisoning are difficult to identify earlier [32]. The lethal dose of arsenic is $2 \mathrm{mg} / \mathrm{kg} / \mathrm{day}$ [8]. Further research is needed to identify the effects of arsenic exposure in the community around the Ie Seu'um geothermal area. However, because of the indirect effect of arsenic exposure, the most rational action is prevention [32].

Age and exposure level did not show a linear relationship. Although high arsenic levels were detected in the majority of older respondents, low arsenic levels were not indicated by younger respondents. This was due to the higher drinking needs of the age range of 19-29 years compared with the older one. This caused the young people to be more exposed to arsenic. Apart from being affected by the duration of contamination, arsenic accumulation in the body is also influenced by the intensity of the contamination. Therefore, the arsenic levels in hair are influenced not only by age but also by other factors such as the intensity and sources of exposure, such as contaminated drinks and foods [32]. 


\section{Conclusions}

A validated method has been applied to analyze the arsenic levels in the water, sediment, and hair samples of residents in the Ie Seu'um geothermal area using GF-AAS. This method was very linear and sensitive and has good \%Recovery and precision with a correlation coefficient of $0.9999, \mathrm{LoD}$ of $0.009 \mu \mathrm{g} / \mathrm{L}, \mathrm{LoQ}$ of $0.027 \mu \mathrm{g} / \mathrm{L}$, recovery of $89.117-101.027 \%$ for hair samples and $88.337-105.175 \%$ for sediment samples, and RSD of $1.067 \%$. The sample test results showed that the hot springs contained the highest arsenic with levels of $166.73 \pm 0.0081 \mu \mathrm{g} / \mathrm{L}$ (IS1). Meanwhile, the water samples in the rivers that had not been in direct contact with the hot water (IS2) flow had the lowest arsenic content, which is $0.80 \pm 0.0036 \mu \mathrm{g} / \mathrm{L}$. All the river water samples that had been in contact with hot water, resident boreholes, and the boreholes located around the hot water streams/rivers were contaminated with arsenic above the water quality standard for both drinking water and clean water. Only the river water that had not been in contact with hot water and water treatment was detected with an arsenic level below the drinking water quality standard. In addition, the resident boreholes located far from the hot water flow were detected with an arsenic level below the clean water quality standard. All the sediment samples showed an arsenic contamination with levels between 2.56 and $6.86 \mathrm{mg} / \mathrm{kg}$ but were still within the normal limits recommended by the NOAA. The arsenic exposures in communities around the geothermal area were very high, where 9 out of 10 respondents were positive for arsenic with levels of $54.59-164.57 \mathrm{mg} / \mathrm{kg}$, which were already above the threshold set by the researchers.

Author Contributions: Conceptualization, R.I. and M.A.; data curation, M.A., M.M., A.L., M.Y., S.S. and Z.J.; formal analysis, E.S. (Eko Suhartono), M.M., M.Y. and E.S. (Eka Safitri); funding acquisition, R.I.; investigation, I.I., E.S. (Eko Suhartono), A.L., S.S. and K.S.; methodology, U.Z., M.A., E.S. (Eko Suhartono) and K.S.; project administration, I.I.; resources, R.I.; software, I.I., U.Z., G.M.I., A.L., M.Y. and E.S. (Eka Safitri); supervision, R.I.; validation, R.I., M.A., E.S. (Eko Suhartono), G.M.I., M.M. and Z.J.; visualization, U.Z.; writing —original draft, I.I. and U.Z.; writing—review and editing, I.I., R.I., U.Z., E.S. (Eko Suhartono), G.M.I., M.M., M.Y., S.S., K.S., E.S. (Eka Safitri) and Z.J. All authors have read and agreed to the published version of the manuscript.

Funding: This research was supported by the doctoral scholarship research funding from the Indonesian Ministry of Health (address: Jl H.R.Rasuna Said Blok X.5 Kav. 4-9, Blok A, Lt.6, Jakarta, Indonesia; ministerial decision letter: Nomor HK.02.02/III/416/2018).

Institutional Review Board Statement: This study was approved by Komisi Etik Penelitian Kesehatan Politeknik Kesehatan Kementerian Kesehatan Aceh (KEPT POLTEKKES KEMENKES ACEH), No.LB.02.03/6.7/02.02/2020.

Informed Consent Statement: Written informed consent has been obtained from the all participants to publish this paper.

Data Availability Statement: The data in this study are available upon request to the author.

Acknowledgments: The authors would like to thank the Indonesian Ministry of Health as the research funder.

Conflicts of Interest: The authors declare no conflict of interest.

\section{References}

1. Zhang, X.; Hu, Q. Development of Geothermal Resources in China: A Review. J. Earth Sci. 2018, 29, 452-467. [CrossRef]

2. Idroes, R.; Yusuf, M.; Saiful, S.; Alatas, M.; Subhan, S.; Lala, A.; Muslem, M.; Suhendra, R.; Idroes, G.M.; Marwan, M.; et al. Geochemistry Exploration and Geothermometry Application in the North Zone of Seulawah Agam, Aceh Besar District, Indonesia. Energies 2019, 12, 4442. [CrossRef]

3. Idroes, R.; Yusuf, M.; Alatas, M.; Lala, A.; Suhendra, R.; Idroes, G.M. Marwan Geochemistry of Sulphate spring in the Ie Jue geothermal areas at Aceh Besar district, Indonesia. In Proceedings of the Annual International Conferences, Banda Aceh, Indonesia, 12 September 2018; IOP Conference Series: Materials Science and Engineering; IOP Publishing: Bristol, UK, 2019; Volume 523, p. 012012. [CrossRef] 
4. Suhartono, E.; Noor, Z.; Edyson Budianto, W.Y.; Idroes, R. Effect of chronic lead exposure on bone using ATR-FTIR spectroscopy. In Proceeding of the International Conference on Bioinformatics and Nano-Medicine from Natural Resources for Biomedical Research, Malang, Indonesia, 21 November 2018; AIP Publishing: Melville, NY, USA, 2019; Volume 2108, p. 020025.

5. Anawar, H.M.; Garcia-Sanchez, A.; Santa Regina, I. Evaluation of various chemical extraction methods to estimate plant-available arsenic in mine soils. Chemosphere 2008, 70, 1459-1467. [CrossRef] [PubMed]

6. Hung, D.Q.; Nekrassova, O.; Compton, R.G. Analytical methods for inorganic arsenic in water: A review. Talanta 2004, 64, 269-277. [CrossRef] [PubMed]

7. Santra, B.K. Arsenic Contamination of Groundwater in West Bengal: Awareness for Health and Social Problems. Int. J. Appl. Sci. Eng. 2017, 5, 43. [CrossRef]

8. ATSDR. Toxicological Profile for Arsenic. Departement of Health and Human Services; ATSDR CDC: Atlanta, GA, USA, 2007.

9. $\quad$ Petrucci, R.H. Kimia Dasar; Terjemahan; Erlangga: Jakarta, Indonesia, 1982.

10. Vogliardi, S.; Tucci, M.; Stocchero, G.; Ferrara, S.D.; Favretto, D. Sample preparation methods for determination of drugs of abuse in hair samples: A review. Anal. Chim. Acta 2015, 857, 1-27. [CrossRef]

11. Guo, Q.; Planer-Friedrich, B.; Liu, M.; Yan, K.; Wu, G. Magmatic fluid input explaining the geochemical anomaly of very high arsenic in some southern Tibetan geothermal waters. Chem. Geol. 2019, 513, 32-43. [CrossRef]

12. Herath, I.; Vithanage, M.; Bundschuh, J.; Maity, J.P.; Bhattacharya, P. Natural Arsenic in Global Groundwaters: Distribution and Geochemical Triggers for Mobilization. Curr. Pollut. Rep. 2016, 2, 68-89. [CrossRef]

13. Birkle, P.; Bundschuh, J.; Sracek, O. Mechanisms of arsenic enrichment in geothermal and petroleum reservoirs fluids in Mexico. Water Res. 2010, 44, 5605-5617. [CrossRef] [PubMed]

14. Yüksel, B.; Mergen, G.; Soylemezoglu, T. Assessment of Arsenic Levels in Human Hair by Hydride Generation Atomic Absorption Spectrometry: A Toxicological Application. At. Spectrosc.-Norwalk Connect. 2010, 31, 1-5.

15. Yüksel, B.; Kayaalti, Z.; Soylemezoglu, T.; TURKSOY, V.; Tutkun, E. GFAAS Determination of Arsenic Levels in Biological Samples of Workers Occupationally Exposed to Metals: An Application in Analytical Toxicology. At. Spectrosc. 2015, 36, 171-176. [CrossRef]

16. SNI 6989.8; Air Dan Limbah—Bagian 8: Cara Uji Timbal (Pb) Secara Spektrofotometri Serapan Atom (SSA); SNI: Jakarta, Indonesia, 2009.

17. US EPA Operating Procedure. Sediment Sampling; EPA: Washington, DC, USA, 2010.

18. SNI 6992.8; Sedimen-Bagian 8: Cara uji Seng (Zn) Secara Destruksi Asam Dengan Spektrofotometer Serapan Atom (SSA); SNI: Jakarta, Indonesia, 2017.

19. SNI 4866; Cara Uji Cemaran Arsen dalam Makanan. Penerbit Badan Standarisasi Nasional; SNI: Jakarta, Indonesia, 1998.

20. US EPA Method 7010; Graphite Furnace Atomic Absorption Spectrophotometry; EPA: Washington, DC, USA, 2007.

21. Skoog, D.A. Fundamentals of Analytical Chemistry; Thomson: Hampshire, UK, 2004.

22. Christian, G.D.; Dasgupta, P.K.; Schug, K.A. Analytical Chemistry; Wiley: Hoboken, NJ, USA, 2013.

23. Menkes, R. Peraturan Menteri Kesehatan Republik Indonesia Nomor 492 Tahun 2010 Tentang Persyaratan Kualitas Air Minum; KEMENKES RI: Jakarta, Indonesia, 2010.

24. Maity, J.P.; Ho, P.-R.; Huang, Y.-H.; Sun, A.-C.; Chen, C.-C.; Chen, C.-Y. The removal of arsenic from arsenic-bearing groundwater in In-situ and Ex-situ environment using novel natural magnetic rock material and synthesized magnetic material as adsorbent: A comparative assessment. Environ. Pollut. 2019, 253, 768-778. [CrossRef] [PubMed]

25. Horwitz, W. AOAC guidelines for single laboratory validation of chemical methods for dietary supplements and botanicals. Gaithersburg MD USA AOAC Int. 2002, 1, 12-19.

26. Menkes, R. Peraturan Menteri Kesehatan Republik IndonesiaNomor 32 Tahun 2017 Tentang Standar Baku Mutu Kesehatan Lingkungan dan Persyaratan Kesehatan Air untuk Keperluan Higiene Sanitasi, Kolam Renang, Solus per Aqua, dan Pemandian Umum; KEMENKES RI: Jakarta, Indonesia, 2017.

27. WHO Guidelines for Drinking Water Quality, 4th ed.; World Health Organization: Geneva, Switzerland, 2011.

28. Salim, N.A.A.; Wood, A.K.; Yusof, A.M.; Hamzah, M.S.; Elias, M.S.; Rahman, S.A. A study of arsenic and chromium contamination in sediments of freshwater bodies. Fresenius Environ. Bull. 2009, 18, 1618-1623.

29. Wu, B.; Chen, T. Changes in hair arsenic concentration in a population exposed to heavy pollution: Follow-up investigation in Chenzhou City, Hunan Province, Southern China. J. Environ. Sci. 2010, 22, 283-289. [CrossRef]

30. Ali, M.; Tarafdar, S.A. Arsenic in drinking water and in scalp hair by EDXRF A major recent health hazard in Bangladesh. J. Radioanal. Nucl. Chem. 2003, 256, 297-305. [CrossRef]

31. Mayo Clinic Staff Detection of Nanocute Arsenic Expouse in Hair Specimens. Available online: https:/ / neurology.testcatalog. org/show / ASHA (accessed on 23 June 2020).

32. Paul, B.K. Arsenic contamination awareness among the rural residents in Bangladesh. Soc. Sci. Med. 2004, 59, 1741-1755. [CrossRef] 